\title{
Analisis Elastisitas Pendapatan Rumah Tangga di Indonesia
}

\section{(Analysis of Income Elasticity of Household in Indonesia)}

\author{
Dian Hafizah $^{1 *}$, Dedi Budiman Hakim² ${ }^{2}$ Harianto $^{3}$, Rita Nurmalina ${ }^{3}$
}

(Diterima Mei 2020/Disetujui Juli 2021)

\begin{abstract}
ABSTRAK
Permintaan atas produk pangan pasti tidak dapat dihindari, hal ini akibat dari produk pangan sebagai bahan pokok untuk kerberlanjutan hidup manusia. Demikian halnya di Indonesia, permintaan atas pangan sangat bergantung pada kondisi masyarakatnya. Tujuan penelitian ini adalah menganalisis permintaan pangan di Indonesia akibat adanya perubahan pendapatan yang dibagi ke dalam 4 kategori wilayah,yaitu rumah tangga kaya di kota, rumah tangga miskin di kota, rumah tangga kaya di desa, dan rumah tangga miskin di desa. Melalui gambaran ini dapat diperoleh kebijakan yang tepat dalam upaya memenuhi permintaan konsumsi masyarakat di Indonesia. Metode penelitian yang dilakukan adalah menggunakan data sekunder dengan jenis data panel yang diperoleh dari data SUSENAS. Metode analisis yang digunakan untuk mengestimasi sistem permintaan adalah melalui pendekatan ekonometrika, yaitu dengan model QUAIDS kemudian data diolah dengan menggunakan program SAS. Hasil penelitian menunjukkan bahwa proporsi total pengeluaran rumah tangga yang dialokasikan khusus untuk bahan pangan jika diurutkan, yaitu rumah tangga miskin di desa lebih tinggi kemudian diikuti dengan rumah tangga miskin di kota, rumah tangga kaya di kota, dan rumah tangga kaya di desa. Apabila terjadi perubahan pendapatan maka rumah tangga miskin di desa dan rumah tangga miskin di kota pada umumnya masih meresposnya dengan mengalokasikan sebagian besar pendapatannya untuk komoditas yang sangat pokok seperti makanan lain dan tembakau, beras, karbohidrat lainnya, minyak, dan lemak, sementara rumah tangga kaya di desa dan rumah tangga kaya di kota lebih memberikan respons untuk mengalokasikan pendapatannya untuk komoditas daging, buah-buahan, sayuran, ikan, telur, dan susu serta makanan dan minuman olahan.
\end{abstract}

Kata kunci: elastisitas pendapatan, konsumsi, permintaan pangan, quaids

\section{ABSTRACT}

Demand for food products is inevitable, this condition is related to food products as a staple food for the sustainability of human life. In Indonesia, the demand for food depends very much on the needs of the people. The purpose of this study is to analyze food demand in Indonesia which is divided into 4 categories of regions: rich cities, poor cities, rich villages, and poor villages need through research that can be obtained about getting assistance in accordance with the consumption demand of people in Indonesia. The research method used secondary data with panel data types obtained from SUSENAS data. The analytical method used to estimate the demand system was through econometrics demand, namely the QUAIDS model and then the data were processed using the SAS program. The results showed a comparison of the total number of households allocated specifically for food if sorted out, namely poor villages were higher then followed by poor cities, rich cities, and rich villages. When there is a change in income, poor rural households and poor cities when the public still responds by allocating a large part of their budgets to very basic trade such as other food and tobacco, rice, other oils, and household fats in rich villages and rich cities provide more responses to allocating their incomes to the trade in meat, fruits, vegetables, fish, eggs, milk, and processed foods.

Keywords: Quadaric Almost Ideal System, income elasticity, consumption, demand food

\section{PENDAHULUAN}

Jumlah penduduk miskin yang masih besar akan menyulitkan pemerintah dalam mengambil kebijakan

${ }^{1}$ Program Studi Agribisnis, Fakultas Pertanian, Universitas Andalas, Kampus Limau Manis, Padang 20362

2 Departemen IImu Ekonomi, Fakultas Ekonomi dan Manajemen, Institut Pertanian Bogor, Kampus IPB Darmaga, Bogor 16680

3 Departemen Agribisnis, Fakultas Ekonomi dan Manajemen, Institut Pertanian Bogor, Kampus IPB Darmaga, Bogor 16680

* Penulis Korespondensi:

Email: dianhafizah@agr.unand.ac.id dikarenakan golongan ini cenderung untuk memiliki permasalahan ikutan yang menyertai kemiskinan itu sendiri, antara lain dalam kerawanan pangan dan keamanan pangan sehingga berakibat buruk seperti permasalahan kesehatan yang buruk terkait kurangnya asupan makanan, gizi balita buruk hingga dapat menyebabkan kematian. Padahal, sesuai dengan Undang Undang no 18 tahun 2012, pemerintah berkewajiban untuk menyediakan pangan dalam jumlah yang cukup dan menjamin lancarnya akses masyarakat untuk mengkonsumsi komoditas pangan sesuai dengan kebutuhan mereka. Hal ini tertuang dalam pengertian ketahanan pangan, yaitu suatu keadaan di mana pangan dapat dipenuhi baik secara 
umum ataupun perseorangan, yang ditandai dengan jumlah pangan yang cukup secara jumlah ataupun terkait dengan mutu dan kualitas pangan, aman, beragam, bergizi, merata, dan terjangkau serta tidak melanggar ketentuan agama, keyakinan, dan budaya masyarakat untuk dapat hidup sehat, aktif, dan produktif secara berkelanjutan.

Dalam usaha untuk memenuhi kebutuhan rumah tangga baik untuk pangan ataupun untuk kebutuhan nonpangan, rumah tangga akan sangat dipengaruhi oleh kondisi kemiskinan rumah tangga tersebut. Semakin besar proporsi yang dikeluarkan oleh rumah tangga untuk membeli kebutuhan komoditas pangan terhadap pengeluaran total maka dapat dikatakan semakin miskin rumah tangga tersebut (Yusdianto 2016). Pernyataan ini mendukung penelitian yang dilakukan oleh Deaton \& Muellbauer (1980) yang menyatakan bahwa pangsa pengeluaran pangan penduduk yang semakin kecil di suatu negara merupakan indikator makin tingginya kesejahteraan suatu masyarakat.

Wilayah tempat tinggal rumah tangga, yaitu perkotaan dan perdesaan akan memengaruhi perilakunya dalam konsumsi pangan. Hal ini karena karakteristik kedua tipe daerah tersebut berbeda. Dianarafah (1999); Rachman (2001); Ariningsih (2002); Widiasih (2009); Suharno (2010); Pangaribowo \& Tsegai (2011); dan Saputri et al. (2016) menunjukkan bahwa terdapat perbedaan pola konsumsi pangan antara rumah tangga di perkotaan dan di perdesaan. Lebih lanjut Miranti et al. (2016) juga menjelaskan terdapat perbedaan pola konsumsi pangan antara rumah tangga di perdesaan dan perkotaan. Perbedaan yang terjadi dapat dikarenakan perbedaan pendapatan dan harga pangan. Akibat adanya kondisi tersebut maka diperlukan penelitian yang dapat memberikan gambaran dalam rangka menghasilkan kebijakan yang tepat pada masing-masing wilayah di Indonesia yang dianalisis dengan pendekatan Quadaric Almost Ideal System (QUAIDS).

Model QUAIDS adalah bentuk pengembangan dari model AIDS, di mana asumsi linearitas dimasukkan pada fungsi pengeluaran. Model kuadratik dalam pengeluaran per kapita dengan asumsi bahwa ada hubungan non-linear antara pendapatan dan pengeluaran. Beberapa studi permintaan telah mengkonfirmasi kesesuaian QUAIDS dalam preferensi pemodelan, yaitu Abdulai (2002) menerapkan QUAIDS pada data pengeluaran makanan dari Switzerland, Moro dan Sckokai (2000) tentang data pengeluaran makanan Italia, Banks et al. (1997); Blundell \& Robin (1999) menggunakan data pengeluaran barang konsumsi luas dari Inggris, dan Fisher et al. (2001) menerapkan model tersebut ke data konsumsi agregat A.S., Abdulai \& Aubert (2004) pada data pengeluaran makanan Tanzania, Meenkashi \& Ray (1999) menggunakan data pengeluaran makanan India, Gould \& Villarreal (2006) menggunakan data pengeluaran makanan dari perkotaan Cina, Mollina \&
Gil (2005) menggunakan data konsumsi agregat di Peru.

Adapun tujuan penelitian ini adalah mendeskripsikan pola konsumsi pangan rumah tangga di Indonesia dan menganalisis perubahan konsumsi pangan rumah tangga akibat pendapatan di Indonesia.

\section{METODE PENELITIAN}

Penelitian ini menggunakan data sekunder, yaitu data Survei Sosial Ekonomi Nasional (SUSENAS) data konsumsi pada periode Maret 2016 yang dikumpulkan oleh Badan Pusat Statistik (BPS).

Data SUSENAS Panel Konsumsi merupakan data cross section dengan sampling unit rumah tangga. Data yang dikumpulkan dalam SUSENAS terdiri atas data pokok (kor) dan data modul konsumsi. Data kor antara lain adalah keterangan tentang karakteristik rumah tangga, seperti status tempat tinggal (kota/desa), pendidikan, kesehatan, pekerjaan masingmasing anggota rumah tangga, dan perumahan. Sementara itu, data modul konsumsi berisi keterangan rinci tentang pengeluaran rumah tangga untuk setiap jenis komoditas yang dikonsumsi yang dibedakan atas makanan dan nonmakanan serta perincian tentang penerimaan rumah tangga.

Data yang dianalisis dalam penelitian ini mencakup data konsumsi rumah tangga untuk semua jenis komoditas makanan yang terdiri atas kuantitas dan nilai rupiahnya (data modul konsumsi) baik yang berupa produksi sendiri atau dari pembelian, pemberian, dan sebagainya. Adapun data karakteristik rumah tangga (data kor) yang diduga memengaruhi sistem permintaan makanan dimasukkan dalam analisis ini, antara lain seperti tipe daerah (perkotaan dan perdesaan), jumlah anggota rumah tangga, tingkat pendidikan kepala rumah tangga, dan sumber penghasilan utama rumah tangga.

Penelitian ini menggunakan metode analisis ekonometrika dengan data panel untuk mengestimasi sistem permintaan model QUAIDS dan diolah dengan menggunakan program SAS.

Adapun spesifikasi model permintaan dibuat menurut kurva Engel, yaitu kurva yang menunjukkan hubungan antara pendapatan dengan jumlah barang yang diminta dan hubungan antara keduanya bersifat nonlinear. Ketidaklinearan kurva engel ini menunjukkan bahwa sifat barang tidak selalu normal di mana setiap kenaikan pendapatan akan diikuti dengan kenaikan permintaan, namun dapat juga bersifat inferior di mana kenaikan pendapatan akan menurunkan permintaan.

Salah satu model permintaan yang dikembangkan oleh Deaton \& Muellbeuer (1980) adalah model AIDS. Kelebihan model ini adalah merupakan first order approximation pada setiap sistem permintaan, kedua, sesuai dengan aksioma pilihan konsumen di dalam teori permintaan, ketiga mempunyai bentuk fungsi yang konsisten dengan data budget konsumen. Untuk 
mengatasi indeks harga yang bersifat nonlinear maka harus dijadikan linear menggunakan indeks harga stone. Hal ini juga menjadi kelemahan model AIDS karenanya disempurnakan oleh Blundell et al. (1997) dengan model Quaids. Persamaan Quaids sama dengan persamaan Aids ditambah dengan unsur pengeluaran kuadrat sebagai parameter yang digunakan untuk membuktikan bahwa kurva Engel yang nonlinear. Jika nilai koefisien kudrat pendapatan $\left(\lambda_{i}\right)$ adalah nol maka model Quaids akan menjadi Model Aids.

Berdasarkan pertimbangan di atas maka untuk menjawab tujuan penelitian model yang digunakan adalah sistem permintaan dengan two stage budgeting melalui model QUAIDS. Kebijakan pemerintah terkait perberasan tidak berbeda antara satu daerah dengan daerah lainnya sehingga penelitian ini akan membahas berdasarkan perbedaan tingkat pendapatan. Dalam pembahasan nantinya akan dibedakan antara rumah tangga yang tinggal di perdesaan dan rumah tangga yang tinggal di perkotaan. Perbedaan ini dilakukan dengan asumsi bahwa terdapat perbedaan karakteristik antara rumah tangga di desa dan rumah tangga di kota. Tingkat pendapatan dibedakan berdasarkan pembagian pendapatan yang terdapat di Susenas. Langkah pertama pendapatan rumah tangga diurut berdasarkan pendapatannya dari yang paling kecil hingga yang paling besar. Kemudian $40 \%$ dari jumlah rumah tangga selndonesia yang nilainya paling kecil digolongkan sebagai masyarakat miskin, kemudian hasil yang didapat dipisahkan antara kota dan desa. Begitupun perlakuan yang dilakukan untuk rumah tangga dengan golongan pendapatan tinggi di mana $20 \%$ rumah tangga dengan pendapatan total tertinggi digolongkan dalam golongan rumah tangga berpendapatan tinggi kemudian dibagi lagi berdasarkan domisili di perdesaan dan perkotaan.

Dalam penelitian ini barang nonpangan dikeluarkan dari sistem permintaan dengan mengasumsikan fungsi kepuasan yang dapat dipisahkan. Hal ini mengingat bahwa porsi pengeluaran terbesar adalah untuk pangan. Berdasarkan pertimbangan tersebut maka diputuskan untuk mengestimasi sistem demand ke dalam 10 kelompok makanan, yaitu beras, sumber karbohidrat lainnya, ikan, daging, telur dan susu, sayuran, buah-buahan, minyak dan kelapa, makanan dan minuman olahan, makanan lain dan tembakau.

Pada pengelompokan ini diasumsikan harga semua makanan dalam satu kelompok bergerak bersamaan. Asumsi ini sesuai dengan pendapat Nicholson (2008) yang mengatakan bahwa komoditas gabungan adalah kelompok barang di mana semua barang dalam kelompok tersebut bergerak bersamaan sehingga dapat diperlakukan sebagai satu komoditas tunggal.

Diasumsikan bahwa pengeluaran konsumsi makanan dan nonmakanan terjadi pada kondisi yang terpisah sehingga konsumen dapat menentukan preferensinya secara bebas terhadap komoditas makanan tanpa dipengaruhi oleh pengeluaran komoditas nonmakanan dan sebaliknya.
Perhitungan untuk mendapatkan nilai dari share (w) grup didapatkan dengan menjumlahkan setiap pengeluaran untuk komoditas yang digolongkan dalam kelompok yang sama. Kemudian nilai penjumlahan pengeluaran tiap kelompok dibagi dengan total pengeluaran yang dipergunakan untuk membeli semua komoditas pangan, Yang dapat juga dirumuskan sebagai berikut:

$$
\mathrm{w} \_ \text {grup }_{\mathrm{i}}=\sum_{j=1}^{j_{i}} \text { expend }_{j} / \sum_{i=1}^{i_{i}} \text { expend }_{i}
$$

Keterangan:

w_grup $_{\text {i }}=$ Share grup kelompok ke-l,

expend $_{j}=$ Pengeluaran yang dikeluarkan oleh rumah tangga untuk mengkonsumsi komoditas j

expend $_{i}=$ Total pengeluaran yang dikeluarkan oleh rumah tangga untuk mengkonsumsi kelompok pangan-i

Penelitian ini menggunakan pendekatan two-stage budgeting untuk mengestimasi permintaan makanan. Jenjang pertama pengeluaran rumah tangga dikelompokkan menjadi dua kelompok besar, yaitu makanan dan nonmakanan. Pada jenjang kedua pengeluaran makanan dialokasikan ke dalam sepuluh kelompok makanan yang diteliti. Pada tahapan ini diasumsikan terdapat saling keterkaitan di antara kelompok komoditas tersebut sehingga pengeluaran untuk konsumsi makanan merupakan suatu sistem.

Model umum sistem permintaan QUAIDS yang digunakan dalam penelitian ini diformulasikan sebagai berikut, dan pemilihan variabel sosial demografi yang dipilih dengan mempertimbangkan variabel variabel yang digunakan pada penelitian sebelumnya.

$w_{i}=\alpha_{i}+\sum_{j=1}^{n} \gamma_{i j} \ln P_{j}+\beta_{i} \ln \left[\frac{X}{\alpha(p)}\right]+\frac{\lambda_{i}}{b(p)}\left\{\ln \left[\frac{X}{\alpha(p)}\right]\right\}^{2}+d_{k} Z$

Keterangan:

$\mathrm{w}_{\mathrm{i}} \quad=$ Budget share yang dialokasikan untuk komoditas yang ke-I, $\mathrm{P}_{\mathrm{j}}$ adalah harga komoditas $\mathrm{j}$, $\mathrm{X}$ adalah pengeluaran rumah tangga terhadap komoditas, a(P) adalah indeks harga yang dihitung sebagai berikut:

$$
\begin{aligned}
\ln [a(p)]= & \alpha_{0}+\sum_{i=1}^{n} \gamma_{1} \ln P_{i}+0.5 \sum_{i=1}^{n} \sum_{j=1}^{n} \gamma_{i j} \ln p_{i} \ln p_{j} \\
\mathrm{~b}(\mathrm{P}) \quad= & \begin{array}{l}
\text { Harga agregat Cobb Douglas dan } \\
\text { dihitung sebagai berikut: }
\end{array}
\end{aligned}
$$

$$
b(P)=\pi_{i=1}^{n} p_{i}^{\beta^{i}}
$$

$\mathrm{Z}=$ Variabel demografi

$\alpha_{i}, \gamma_{i j}, \beta i=$ Parameter model untuk intersep, harga komoditas, dan pengeluaran riil 
Berdasarkan rumusan di atas maka kemudian dibangun model empiris yang telah disesuaikan dengan kebutuhan penelitian yang dapat dituliskan sebagai berikut :

$\mathrm{w} 1=\mathrm{a} 0+\mathrm{a} 1^{*}\left|\mathrm{np} 1+\mathrm{a} 2^{*} \operatorname{lnp} 2+\mathrm{a} 3^{*} \operatorname{lnp} 3+\mathrm{a} 4^{*}\right| \mathrm{np} 4+\mathrm{a} 5^{*} \operatorname{lnp} 5+\mathrm{a}$ $6^{*} \operatorname{lnp} 6+a 7^{*} \operatorname{Inp} 7+a 8^{*} \operatorname{lnp} 8+a 9^{*} \operatorname{lnp} 9+a 10^{*} \operatorname{Inp} 10+a 11^{*} \operatorname{InL}$ PKRT+a12*InJART+a13*InUMURKK+a14*Ifexp1+a15 *Ifexp2+a16*imr1+a17*u1

$\mathrm{w} 2=\mathrm{b} 0+\mathrm{b} 1^{*} \operatorname{lnp} 1+\mathrm{b} 2^{*} \operatorname{lnp} 2+\mathrm{b} 3^{*} \operatorname{lnp} 3+\mathrm{b} 4^{*} \operatorname{lnp} 4+\mathrm{b} 5^{*} \operatorname{lnp} 5+\mathrm{b}$ $6^{*} \operatorname{lnp} 6+b 7^{*} \operatorname{lnp} 7+b 8 * \operatorname{lnp} 8+b 9^{*} \operatorname{lnp} 9+b 10^{*} \operatorname{lnp} 10+b 11^{*} \operatorname{InL}$ PKRT+b12*InJART+b13*InUMURKK+b14*|fexp1+b15 *Ifexp2+b16*imr2+b17*u1

$w 3=c 0+c 1^{*} \operatorname{lnp} 1+c 2^{*} \operatorname{lnp} 2+c 3^{*} \operatorname{lnp} 3+c 4^{*} \operatorname{lnp} 4+c 5^{*} \operatorname{lnp} 5+c$ $6^{*} \operatorname{Inp} 6+\mathrm{c} 7^{*} \operatorname{Inp} 7+\mathrm{c} 8^{*} \operatorname{Inp} 8+\mathrm{c} 9^{*} \operatorname{Inp} 9+\mathrm{c} 10^{*} \operatorname{lnp} 10+\mathrm{c} 11^{*} \operatorname{InL}$ PKRT+c12*InJART+c13*InUMURKK+c14*|fexp1+c15* Ifexp2+c16*imr3+c17*u1

$\mathrm{w} 4=\mathrm{d} 0+\mathrm{d} 11^{*} \operatorname{lnp} 1+\mathrm{d} 2^{*} \operatorname{lnp} 2+\mathrm{d} 3^{*} \operatorname{lnp} 3+\mathrm{d} 4^{*} \ln 44+\mathrm{d} 5^{*} \operatorname{lnp} 5+\mathrm{d}$ $6^{*} \operatorname{Inp} 6+d 7^{*} \operatorname{Inp} 7+d 8^{*} \operatorname{lnp} 8+d 9^{*} \mid \ln 9+d 10^{*} \operatorname{Inp} 10+\mathrm{d} 11^{*} \operatorname{InL}$ PKRT+d12*InJART+d13*InUMURKK+d14*|fexp1+d15 *Ifexp2+d16*imr4+d17*u1

$w 5=e 0+e 1^{*}\left|n p 1+e 2^{*} \operatorname{lnp} 2+e 3^{*} \operatorname{lnp} 3+e 4^{*}\right| n p 4+e 5^{*} \operatorname{lnp} 5+e$ $6^{*}\left|n p 6+e 7^{*} \operatorname{lnp} 7+e 8^{*} \operatorname{lnp} 8+e 9^{*}\right| n p 9+e 10^{*} \operatorname{lnp} 10+e 11^{*} \operatorname{InL}$ PKRT+e12*InJART+e13*InUMURKK+e14*|fexp1+e15 *Ifexp2+e16*imr5+e17*u1

$w 6=f 0+f 1^{*} \operatorname{lnp} 1+f 2^{*} \operatorname{lnp} 2+f 3^{*} \operatorname{lnp} 3+f 4^{*} \operatorname{lnp} 4+f 5^{*} \operatorname{lnp} 5+f 6^{*} \operatorname{In}$ $\mathrm{p} 6+\mathrm{f} 7^{*} \operatorname{Inp} 7+\mathrm{f} 8^{*} \operatorname{lnp} 8+\mathrm{f} 9^{*} \operatorname{lnp} 9+\mathrm{f} 10^{*} \operatorname{lnp} 10+\mathrm{f} 11^{*} \operatorname{InLPKRT}+$

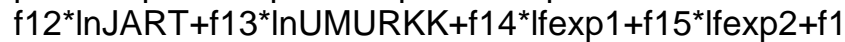
$6^{*} \mathrm{imr} 6+\mathrm{f} 17^{*} \mathrm{u} 1$

$w 7=g 0+g 1^{*}\left|n p 1+g 2^{*} \operatorname{lnp} 2+g 3^{*} \operatorname{lnp} 3+g 4^{*}\right| n p 4+g 5^{*} \operatorname{lnp} 5+g$ $6^{*} \operatorname{lnp} 6+g 7^{*} \operatorname{lnp} 7+g 8^{*} \operatorname{lnp} 8+g 9^{*} \ln 99+g 10^{*} \operatorname{lnp} 10+g 11^{*} \operatorname{lnL}$ PKRT+g12*InJART+g13*InUMURKK+g14*Ifexp1+g15 ${ }^{*}$ Ifexp2+g16*imr7+g17*u1

w8 $=$ h0+h1* $\left|n p 1+h 2^{*} \operatorname{lnp} 2+h 3^{*} \operatorname{lnp} 3+h 4^{*}\right| n p 4+h 5^{*} \operatorname{lnp} 5+h$ $6^{*} \operatorname{lnp} 6+\mathrm{h} 7^{*} \operatorname{Inp} 7+\mathrm{h} 8^{*} \operatorname{lnp} 8+\mathrm{h} 9^{*} \mid \mathrm{np} 9+\mathrm{h} 10^{*} \operatorname{Inp} 10+\mathrm{h} 11^{*} \operatorname{InL}$ PKRT+h12*InJART+h13*InUMURKK+h14*Ifexp1+h15 *Ifexp2+h16*imr8+h17*u1

$w 9=i 0+i 1^{*} \operatorname{Inp} 1+i 2^{*} \operatorname{Inp} 2+i 3^{*} \operatorname{Inp} 3+i 4^{*} \operatorname{Inp} 4+i 5^{*} \operatorname{Inp} 5+i 6^{*} \operatorname{Inp}$ $6+i 7^{*} \operatorname{Inp} 7+i 8^{*} \operatorname{Inp} 8+i 9^{*} \operatorname{Inp} 9+i 10^{*} \operatorname{Inp} 10+i 11^{*} \operatorname{InLPKRT}+i 1$

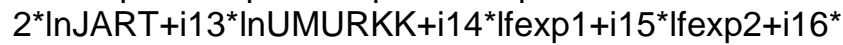
imr9+i17*u1

$w 10=j 0+j 1^{*} \operatorname{lnp} 1+j 2^{*} \operatorname{lnp} 2+j 3^{*} \operatorname{lnp} 3+j 4^{*} \operatorname{lnp} 4+j 5^{*} \operatorname{lnp} 5+j 6^{*} \operatorname{In}$ p6+j7*Inp7+j8* Inp8+j9*Inp9+j10*Inp10+a11*InLPKRT+ a12*InJART+a13*InUMURKK+j14*|fexp1+J15*|fexp2+ j16*imr10+j17*ui

\section{Keterangan:}

$\mathrm{w}_{1}=$ share pengeluaran beras terhadap total pengeluaran makanan

$\mathrm{w}_{2}$ = share pengeluaran sumber karbohidrat lainnya terhadap total pengeluaran makanan
$\mathrm{W}_{3}=$ share pengeluaran ikan terhadap total pengeluaran makanan

$\mathrm{W}_{4}=$ share pengeluaran daging terhadap total pengeluaran makanan

$\mathrm{W}_{5}=$ share pengeluaran telur dan susu terhadap total pengeluaran makanan

$\mathrm{W}_{6}=$ share pengeluaran sayuran terhadap total pengeluaran makanan

$\mathrm{W}_{7}$ = share pengeluaran buah buahan terhadap total pengeluaran makanan

$\mathrm{W}_{8}=$ share pengeluaran minyak dan kelapa terhadap total pengeluaran makanan

$\mathrm{W}_{9}$ = share pengeluaran makanan dan minuman olahan terhadap total pengeluaran makanan

$\mathrm{w}_{10}=$ share pengeluaran makanan lain dan tembakau terhadap total pengeluaran makanan

$\mathrm{P}_{1}=$ harga beras

$\mathrm{P}_{2}=$ harga sumber karbohidrat lainnya

$\mathrm{P}_{3}=$ harga ikan

$\mathrm{P}_{4}=$ harga daging

$P_{5}=$ harga telur dan susu

$\mathrm{P}_{6}=$ harga sayuran

$\mathrm{P}_{7}=$ harga buah buahan

$\mathrm{P}_{8}=$ harga minyak dan kelapa

$\mathrm{P}_{9}=$ harga makanan dan minuman olahan

$\mathrm{P}_{10}=$ harga makanan lain dan tembakau

$\mathrm{a}(\mathrm{P})=$ indeks harga stone untuk makanan

Umur KK = umur kepala keluarga

JART = jumlah anggota rumah tangga

LPKRT = Lama Pendidikan Kepala Rumah tangga

$\mathrm{ai}_{\mathrm{i}}, \mathrm{b}_{\mathrm{ij}}, \mathrm{C}_{\mathrm{ik}}, \mathrm{q}=$ parameter yang diduga

$\mathrm{e}=$ komponen acak

Metode yang digunakan adalah metode SUR (Seemingly Unrelated Regression). Agar konsisten dengan teori utilitas maka dilakukan restriksi terhadap fungsi permintaan, yaitu :

a. adding up

$$
\sum_{k=1}^{n} a_{i}=1, \sum_{i} c_{i k}=\sum q_{i k}=0
$$

b. homogen derajat nol dalam harga

$$
\sum_{k=1}^{n} b_{i j}=0
$$

c. simetri atau $b_{i j}=b_{j i}$ artinya pengaruh perubahan harga barang I terhadap permintaan barang j sama dengan pengaruh perubahan harga barang j terhadap barang $\mathrm{i}$.

Elastisitas harga sendiri dan elastisitas harga silang untuk setiap kelompok pangan dihitung dengan persamaan berikut:

$$
\begin{aligned}
& \eta_{\mathrm{i}}=\left(c_{i 1}+2 c_{i 2} \ln \frac{M}{w_{i}}\right)+1 \\
& \epsilon_{\mathrm{i}}=\left(\frac{b_{i j}}{w_{i}}\right)-\left(c_{i 1}+2 c_{i 2} \ln (M)\right)\left(\frac{w_{i}}{w_{i}}\right)-\delta_{i j}
\end{aligned}
$$

Di mana $\delta_{i j}$ adalah Delta Kronecker, maka nilai elastisitas harga sendiri pada suatu kelompok pangan 
nilainya adalah 1 , dan nilai elastisitas silangnya adalah 0 sementara wi adalah pangsa (share value) dari kelompok makanan-i.

\section{HASIL DAN PEMBAHASAN}

Arti elastisitas pendapatan adalah berapa persentase perubahan jumlah barang yang diminta akibat adanya perubahan pendapatan yang diterima oleh rumah tangga sebesar $1 \%$. Dalam data SUSENAS nilai pendapatan didekati dengan menggunakan total nilai pengeluaran yang dikeluarkan oleh rumah tangga untuk membeli sejumlah komoditas tertentu, sedangkan variabel lainnya tetap (ceteris paribus).

Berdasarkan hasil penelitian menunjukkan bahwa elastisitas pendapatan pada konsumsi pangan rumah tangga di Indonesia pada tahun 2016 dapat dilihat pada Tabel 1. Penjelasannya adalah secara nasional pada saat pendapatan rumah tangga meningkat sebesar $1 \%$ maka permintaan beras akan meningkat juga sebesar $0,431 \%$. Imbas dari nilai tersebut adalah pemerintah pada saat mengambil kebijakan terkait perubahan pendapatan juga harus mempertimbangkan penambahan permintaan beras yang akan makin membebani pemerintah untuk mencukupi penambahan permintaan tersebut. Informasi lain yang dapat diambil dari nilai elastisitas pendapatan ini antara lain adalah bahwa rumah tangga di Indonesia masih mengutamakan penambahan beras pada saat terjadi penambahan pendapatan, artinya beras adalah komoditas penting dalam proporsi pengeluaran rumah tangga.

Adapun elastisitas karbohidrat lainnya terhadap pendapatan total rumah tangga di Indonesia sebesar 0,510, sedangkan elastisitas karbohidrat lainnya terhadap pendapatan pada masing-masing wilayah jika diurutkan mulai dari nilai elastisitas karbohidrat lainnya terhadap pendapatan yang memiliki nilai paling tinggi hingga paling rendah adalah rumah tangga miskin di desa $(0,718)$, rumah tangga kaya di kota $(0,508)$, rumah tangga miskin di kota $(0,433)$, rumah tangga kaya di desa (0.334). Artinya, elastisitas karbohidrat lainnya yang sangat responsif terhadap pendapatan adalah masyarakat yang berada pada rumah tangga miskin di desa dan yang paling tidak responsif adalah rumah tangga kaya di desa. Hal ini menggambarkan bahwa alokasi pendapatan masyarakat di rumah tangga miskin di desa lebih memilih mengalokasikannya pada komoditas karbohidrat lainnya dan juga beras dibandingkan dengan komoditas lainnya, namun hal ini berbeda dari wilayah lainnya.

Kemudian nilai elastisitas permintaan ikan terhadap pendapatan di Indonesia sebesar 0,425, sedangkan elastisitas permintaan ikan terhadap pendapatan pada masing-masing wilayah jika diurutkan mulai dari nilai elastisitas permintaan ikan terhadap pendapatan yang memiliki nilai paling tinggi hingga paling rendah adalah rumah tangga miskin di desa $(0,689)$, rumah tangga miskin di kota $(0,361)$, rumah tangga kaya di desa $(0,249)$, dan rumah tangga kaya di kota $(0,211)$. Makna yang dapat diuraikan pada bagian ini adalah masyarakat desa miskin lebih responsif dalam mengalokasikan pendapatannya untuk membeli ikan jika dibanding dengan di kota miskin, desa kaya, dan kota kaya.

Selanjutnya nilai elastisitas daging terhadap pendapatan di Indonesia sebesar 0,490, sedangkan elastisitas permintaan daging terhadap pendapatan pada masing-masing wilayah jika diurutkan mulai dari nilai elastisitas daging terhadap pendapatan yang memiliki nilai paling tinggi hingga paling rendah adalah rumah tangga kaya di kota $(0,835)$, rumah tangga miskin di desa $(0,686)$, rumah tangga miskin di kota $(0,392)$, dan rumah tangga kaya di desa $(0,313)$. Hal ini menunjukkan bahwa rumah tangga kaya di kota lebih memilih mengalokasikan pendapatan totalnya terhadap komoditas daging dibandingkan dengan ikan sebagai lauk pauk dalam konsumsinya dan hal ini berbeda dari masyarakat di desa miskin, kota miskin, dan desa kaya. Nilai elastisitas telur susu dan kacangkacangan terhadap pendapatan di Indonesia sebesar 0,525 , sedangkan elastisitas permintaan telur dan susu terhadap pendapatan pada masing-masing wilayah jika diurutkan mulai dari nilai elastisitas telur dan susu terhadap pendapatan yang memiliki nilai paling tinggi hingga paling rendah adalah rumah tangga miskin di desa $(0,614)$, rumah tangga miskin di kota $(0,542)$, rumah tangga kaya di kota $(0,478)$, rumah tangga kaya

Tabel 1 Elastisitas pendapatan rumah tangga di Indonesia pada Tahun 2016

\begin{tabular}{|c|c|c|c|c|c|}
\hline \multirow[b]{2}{*}{ Jenis komoditas } & \multicolumn{2}{|c|}{ Desa } & \multicolumn{2}{|c|}{ Kota } & \multirow[b]{2}{*}{ Nasional } \\
\hline & $\begin{array}{c}\text { Rumah tangga } \\
\text { kaya }\end{array}$ & $\begin{array}{l}\text { Rumah tangga } \\
\text { miskin }\end{array}$ & $\begin{array}{c}\text { Rumah } \\
\text { tangga kaya }\end{array}$ & $\begin{array}{c}\text { Rumah tangga } \\
\text { miskin }\end{array}$ & \\
\hline Beras & 0,256 & 0,583 & 0,189 & 0,323 & 0,431 \\
\hline Karbohidrat lain & 0,334 & 0,719 & 0,508 & 0,434 & 0,510 \\
\hline Ikan & 0,250 & 0,689 & 0,211 & 0,361 & 0,425 \\
\hline Daging & 0,313 & 0,686 & 0,836 & 0,392 & 0,490 \\
\hline Telur susu dan kacang & 0,221 & 0,614 & 0,478 & 0,542 & 0,525 \\
\hline Sayur & 0,275 & 0,592 & 0,297 & 0,600 & 0,521 \\
\hline Buah & 0,194 & 0,426 & 0,642 & 0,373 & 0,363 \\
\hline Lemak & 0,322 & 0,779 & 0,306 & 0,523 & 0,572 \\
\hline $\begin{array}{l}\text { Bahan minuman, bumbu, } \\
\text { dan konsumsi lain }\end{array}$ & 0,326 & 0,810 & 0,325 & 0,555 & 0,629 \\
\hline Rokok dan makanan jadi & 0,619 & 1,394 & 0,722 & 1,233 & 1,086 \\
\hline
\end{tabular}


di desa $(0,221)$. Indikasi kondisi ini menjelaskan bahwa rumah tangga miskin di desa lebih responsif dalam mengalokasikan pendapatannya untuk membeli telur dan susu dibandingkan dengan wilayah lainnya.

Nilai elastisitas sayuran terhadap pendapatan total rumah tangga di Indonesia sebesar 0,521 sedangkan elastisitas permintaan sayuran terhadap pendapatan pada masing-masing wilayah jika diurutkan mulai dari nilai elastisitas sayuran terhadap pendapatan yang memiliki nilai paling tinggi hingga paling rendah adalah rumah tangga miskin di kota $(0,600)$, rumah tangga miskin di desa $(0,592)$, rumah tangga kaya di kota $(0,297)$, dan rumah tangga kaya di desa $(0,275)$. Artinya dalam hal ini rumah tangga miskin di kota lebih mengalokasi total pendapatannya untuk membeli sayuran dan ini menunjukkan bahwa rumah tangga miskin di kota lebih responsif memilih sayuran dibandingkan dengan masyarakat di wilayah lainnya.

Nilai elastisitas buah-buahan terhadap pendapatan di Indonesia sebesar 0.363 sedangkan elastisitas buah-buahan terhadap total pendapatan pada masingmasing wilayah jika diurutkan mulai dari nilai elastisitas buah-buahan terhadap pendapatan yang memiliki nilai paling tinggi hingga paling rendah adalah rumah tangga kaya di kota $(0,642)$, rumah tangga miskin di desa $(0,426)$, rumah tangga miskin di kota $(0,373)$, dan rumah tangga kaya di desa $(0,193)$. Artinya dari nilai elastisitas yang diperoleh kota kaya ternyata lebih responsif memilih buah-buahan dibandingkan dengan masyarakat di wilayah lainnya.

Nilai elastisitas lemak terhadap pendapatan di Indonesia sebesar 0,572, sedangkan elastisitas lemak terhadap total pendapatan pada masing-masing wilayah jika diurutkan mulai dari nilai elastisitas minyak dan lemak terhadap pendapatan yang memiliki nilai paling tinggi hingga paling rendah adalah rumah tangga miskin di desa $(0,778)$, rumah tangga miskin di kota $(0,523)$, rumah tangga kaya di desa $(0,322)$, rumah tangga kaya di kota $(0,306)$. Artinya dari nilai yang diperoleh ternyata rumah tangga miskin di desa lebih responsif memilih lemak dibandingkan dengan masyarakat di wilayah lainnya.

Nilai elastisitas bumbu bahan minuman dan makanan lainnya terhadap total pendapatan di Indonesia sebesar 0,629, sedangkan elastisitas bumbu bahan minuman dan makanan lainnya terhadap pendapatan pada masing-masing wilayah jika diurutkan mulai dari nilai elastisitas bumbu bahan minuman dan makanan lainnya terhadap pendapatan yang memiliki nilai paling tinggi hingga paling rendah adalah rumah tangga miskin di desa $(0,810)$, rumah tangga miskin di kota $(0,555)$, rumah tangga kaya di desa $(0,325)$, dan rumah tangga kaya di kota $(0,325)$. Artinya dari nilai yang diperoleh rumah tangga miskin di desa dan rumah tangga miskin di kota lebih responsif memilih bumbu bahan minuman dan makanan lainnya dibandingkan dengan masyarakat di kelompok rumah tangga kaya di desa dan rumah tangga kaya di kota. Maka dapat diuraikan lebih lanjut bahwa masyarakat miskin akan lebih memilih makanan dan minuman olahan pada alokasi pendapatannya kemudian rumah tangga kaya baik di desa maupun di kota.

Nilai elastisitas rokok dan makanan jadi terhadap pendapatan di Indonesia sebesar 1,086, sedangkan elastisitas rokok dan makanan jadi terhadap pendapatan pada masing-masing wilayah jika diurutkan mulai dari nilai elastisitas makanan lain dan tembakau terhadap total pendapatan rumah tangga di Indonesia yang memiliki nilai paling tinggi hingga paling rendah adalah rumah tangga miskin di desa $(1,393)$, rumah tangga miskin di kota $(1,233)$, rumah tangga kaya di kota $(0,721)$, dan rumah tangga kaya di desa (0,618). Artinya dari nilai elastisitas yang diperoleh desa miskin dan kota miskin lebih responsif memilih makanan lain dan tembakau dibandingkan dengan masyarakat di wilayah rumah tangga kaya di kota dan rumah tangga kaya di desa. Maka dapat dipastikan bahwa masyarakat miskin lebih mengalokasikan pendapatannya untuk membeli rokok dan makanan jadi.

Pada umumnya hasil penelitian ini searah dengan beberapa peneliti lainnya yang menganalisis permintaan pangan untuk lingkup seluruh Indonesia seperti Harianto (1994); Yuliana (2008); dan Wahyuni et al. (2016), tanpa membedakan kelompok rumah tangga. Dianarafah (1999); Saputri et al. (2016) membedakan analisis permintaan pangan untuk daerah perkotaan dan perdesaan, namun masingmasing hanya untuk Provinsi Jawa Timur dan Provinsi Kalimantan Timur. Yusdiyanto (2016) menganalisis permintaan pangan rumah tangga miskin di Provinsi Sulawesi Tengah.

Hasil penelitian ini senada dengan penelitian Pangaribowo \& Tsegai (2011) yang membedakan analisis permintaan pangan untuk rumah tangga miskin dan tidak miskin serta wilayah perkotaan dan perdesaan untuk lingkup seluruh Indonesia. Dalam penelitiannya disebutkan bahwa terdapat respons dan perbedaan yang sangat terlihat pada masing-masing rumah tangga yang berada di desa maupun kota dengan tingkat pendapatan yang berbeda pula sehingga akan berdampak pada perilaku masingmasing rumah tangga dalam mengalokasikan pendapatannya pada komoditas pangan yang dikonsumsi.

Berdasarkan hasil penelitian Mittal (2010) yang melakukan penelitian pada rumah tangga di India mengungkapkan hal yang sama, di mana pada penelitian tersebut diperoleh bahwa pengeluaran rumah tangga pada umumnya yang tinggal di desa akan mengalokasikan pendapatannya untuk membeli bahan pangan dibanding dengan rumah tangga kota, namun penelitian tersebut tidak membagi antara desa miskin atau kaya maupun kota miskin maupun kaya.

\section{KESIMPULAN}

Pola konsumsi pangan rumah tangga di Indonesia berdasarkan data SUSENAS 2016 dapat dikatakan 
bahwa tingkat partisipasi yang paling tinggi dari 10 komoditas pangan ditempati oleh beras, yaitu sebesar $97,27 \%$ di mana tingkat partisipasi untuk mengkonsumsi daging adalah yang paling rendah, yaitu sebesar $44,20 \%$. Adapun rata-rata pengeluaran total rumah tangga paling tinggi dialokasikan untuk membeli rokok dan makanan jadi, yaitu sebesar 34,7\%, sedangkan pengeluaran beras menempati posisi kedua, yaitu sebesar $17,60 \%$ dari total pengeluaran. Lebih lanjut dapat dijelaskan bahwa share untuk membeli beras pada daerah miskin (perkotaan dan perdesaan) lebih tinggi dibandingkan dengan daerah kaya. Secara umum tidak semua rumah tangga yang telah mengkonsumsi pangan sumber protein baik hewani maupun nabati, padahal protein sangat dibutuhkan untuk pembentukan tulang dan kecerdasan otak.

Berdasarkan hasil penelitian dan pembahasan di atas maka dapat disimpulkan bahwa apabila terjadi perubahan pendapatan maka rumah tangga desa miskin dan kota miskin pada umumnya masih meresponsnya dengan mengalokasikan sebagian besar pendapatannya pada komoditas yang sangat pokok seperti makanan lain dan tembakau, beras, karbohidrat lainnya, minyak, dan lemak sementara rumah tangga di desa kaya dan kota kaya lebih memberikan respons untuk mengalokasikan pendapatannya pada komoditas daging, buah-buahan, sayuran, ikan, telur, dan susu serta makanan dan minuman olahan.

\section{DAFTAR PUSTAKA}

Abdulai. 2002. Household demand for food in Switzerland. A quadratic almost ideal demand system. Swiss Journal of Economic Statistics, 138(1): 1-18. https://doi.org/10.1111/j.15740862.2004.tb00222.x

Abdulai, Aubert D, 2004, A cross-section analysis of household demand for food and nutrients in Tanzania.Agricultural Economics. 3 (1): 67-79.

Ariningsih E. 2002. Perilaku konsumsi pangan sumber protein hewani dan nabati sebelum dan pada masa krisis ekonomi di Jawa [Tesis]. Bogor (ID): Institut Pertanian Bogor.

Banks J, Blundell R, Lewbel A. 1997. Quadratic Engel curves and consumer demand. Review of Economics and Statistics. 4(1): 527-539. https:// doi.org/10.1162/003465397557015

Blundell RW, Robin JM. 1999, Estimation in Large and Disaggregated Demand Systems: An Estimator for Conditionally Linear Systems. Journal of Applied Econometrics, 14(1): 209-232. https://doi.org/ 10.1002/(SICI)1099-1255(199905/06)14:3<209:: AID-JAE532>3.0.CO;2-X
Dianarafah D. 1999. Analisis konsumsi pangan di Propinsi Jawa Timur [Tesis]. Bogor (ID): Institut Pertanian Bogor.

Deaton A, Muellbauer J. 1980. An Almost Ideal Demand System. American Economic Review 70(3): 312-326.

Fisher D, Fleissig AR, Serletis A. 2001. An empirical comparison of flexible demand system functional forms. Journal of Applied Econometrics, 16(1): 59-80. https://doi.org/10.1002/jae.585

Gould W, Villarreal HJ. 2006. An Assessment of the Current Structure of Food Demand in Urban China. Agricultural Economics. 34(1): 1-16. https:// doi.org/10.1111/j.1574-0862.2006.00098.x

Harianto. 1994. An empirical analysis of food demand in Indonesia: a crosssectional study [Dissertation].Victoria (US). La Trobe University.

Nicholson W, Snyder C. 2007. Microeconomic Theory: Basic Principles And Extentions. South-Western (US) Thomson Corporation.

Meenakshi JV, Ray R., 1999. Regional Differences in India's Food Expenditure Pattern: A Completed Demand Systems Approach. Journal of International Development. 11(1): 47-74. https:// doi.org/10.1002/(SICI)1099-1328(199901/02)11: 1<47::AID-JID549>3.0.CO;2-Y

Miranti A, Syaukat Y, Harianto. 2016. Pola konsumsi pangan rumahtangga di Provinsi Jawa Barat. Jurnal Agro Ekonomi. 34(1): 67-80. https://doi.org/ 10.21082/jae.v34n1. 2016.67-80

Mittal, Surabhi. 2008. Application of the Quaids Model to the Food Sector in India. Journal of Quantitative Economics. 8(1): 36-42.

Molina JS, Gil Al. 2005. The Demand Behavior of Consumers in Peru: A Demographic Analysis using the QUAIDS. Journal of Developing Areas. 39(1): 191-206. https://doi.org/10.1353/jda.2005.0038

Moro D, Sckokai P. 2000, Heterogenous Preferences in Household Food Consumption in Italy. European Review of Agricultural Economics. 27(3): 305-323. https://doi.org/10.1093/erae/27.3.305

Pangaribowo EH, Tsegai D. 2011. Food demand analysis of Indonesian households with particular attention to the poorest. ZEF-Discussion Papers on Development Policy No. 151. Zentrum für Entwicklungstorschung, Center for Development Research. Bonn (DE): University Bonn.

Rachman HPS. 2001.Kajian pola konsumsi dan permintaan pangan di Kawasan Timur Indonesia [Disertasi]. Bogor (ID): Institut Pertanian Bogor.

Saputri R, Lestari LA, Susilo J. 2016. Pola konsumsi pangan dan tingkat ketahanan pangan rumah tangga di Kabupaten Kampar Provinsi Riau. Gizi 
Klinis Indonesia. 12(3): 123-130. https://doi.org/ 10.22146/ijcn.23110

Suharno. 2010. An almost ideal demand system for food based on cross section data: rural and urban East Java, Indonesia [dissertation]. Göttingen (DE): Georg-August-Universität Göttingen.

Wahyuni D, Purnastuti L, Mustofa. 2016. Analisis elastisitas tiga bahan pangan sumber protein hewani di Indonesia. Jurnal Economia. 12(1):43-53. https://doi.org/10.21831/economia. v12i1.9544
Widiasih SCL. 2009. Analisis konsumsi dan kebutuhan untuk konsumsi pangan di Provinsi Sumatera Barat, Jawa Tengah, dan Sulawesi Tenggara Tahun 20052015 [Tesis]. Bogor (ID): Institut Pertanian Bogor.

Yuliana R. 2008. Evaluasi perubahan tingkat kesejahteraan rumahtangga sebagai dampak kenaikan harga BBM di Indonesia, periode Pebruari 2005-Maret 2006 [tesis]. Depok (ID): Universitas Indonesia

Yusdiyanto S. 2016. Pola konsumsi pangan rumahtangga miskin di Provinsi Sulawesi Tengah [tesis]. Bogor (ID): Institut Pertanian Bogor. 